UJBM, Vol. 2, No. 2, July - December 2003, pp 85-93

ISSN 0975-3311

https:/ / doi.org/ 10.12725/ ujbm.3.9

\title{
KSFC AND NORTH KARNATAKA
}

\author{
H.S. Anitha* and A.S. Laxmisha**
}

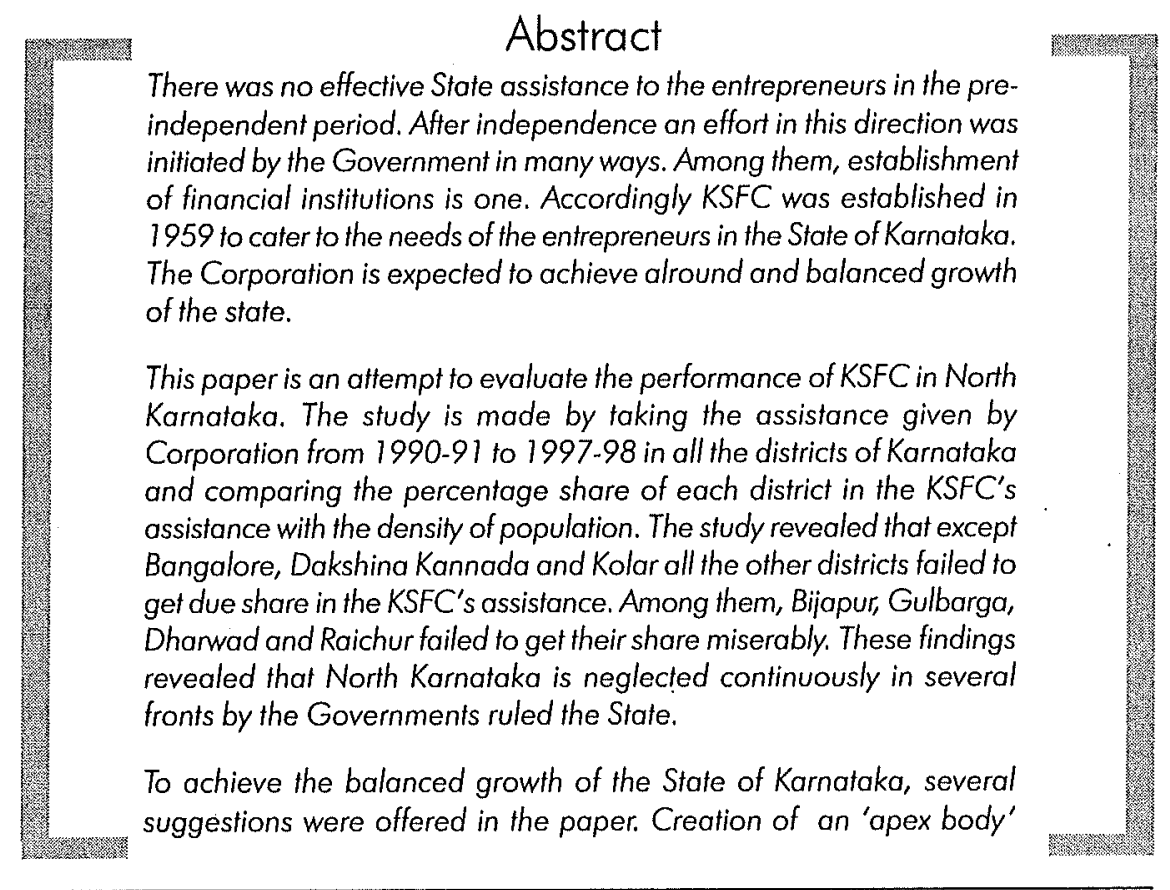

* Department of P.G. Siudies in Commerce, Kuvempu University P.G. Centre, Davanagere Karnataka

** Lecturer, L.B.A.S and S.B.S.C. College, Sagar - Shimoga District, Karnataka 
subordinate of KSFC in North Karnataka, exemption of application processing fees for units coming up in North Karnataka, establishment of 'Technical Advice and Guidance Cell', conducting special developmental campaigns, development of infrastructural facilities etc., are the important suggestions offered by the paper.

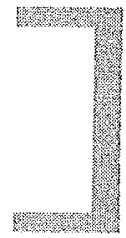

\section{Prelude:}

The entrepreneurs are the backbone of any nation. For a developing nation like India, which aims to achieve a rapid and regionally balanced economic growth through industrialisation and aims to alleviate many a social and economic evils such as poverty, backwardness, unemployment etc., the emergence of large number of entrepreneurs is a vital necessity. Therefore, special efforts were made by the Governments ruling the country i.e., to facilitate entrepreneurship. Among them establishment of financial institutions is one. After independence the institutions like $\mid \mathrm{FCl}, \mathrm{IDBl}, \mathrm{ICICl}, \mathrm{SIDB}$ etc., were created by the Union Government and State Financial Corporations (SFCs) Act was enacted in 1951, which authorised all the State Governments to start their own financial institution to cater to the financial requirements of the entrepreneurs. According to SFCs Act of 1951, Karnataka State Financial Corporation (KSFC) was established in 1959 to finance and promote the entrepreneurs in all the parts of Karnataka State.

The present paper is an attempt to see whether the North Karnataka, part of Karnataka state has been properly allocated (financially) by KSFC or neglected by it. This is because even after so many programmes, policies and schemes of the Government, the state has not been able to achieve a balanced economic growth and industrialisation. For instance, for many years 'Bidar' district in north Karnataka part of the State was declared as 'No Industry District'. The post-independence history of Karnataka. State reveals that large number of big and medium industries were concentrated in and around 5 districts of South Karnataka such as Bangalore, Mysore, Tumkur, Mandya and Kolar. The continued negligence in many-a-front (like industry, education, irrigation etc.) by the Governments that ruled the State of Karnataka since independence, resulted in the demand for a separate 'North Karnataka' state. Delay in starting of a bench of Karnataka High Court and Railway Zone at Hubli, negligence of Bagalkot city, which is sinking now due to an irrigation project etc., are fueling the above demand.

In view of all these, the present paper is developed to evaluate whether the KSFC was able to provide justice in the allocation of its funds to districts of Karnataka (more particularly North Karnataka). It is done by studying / analysing the areawise or district-wise allocation of funds made by KSFC from 1 st April 1990 to 31 st March 1998. 
The KSFC has classified the districts in the Karnataka state into two backward districts and other/non-backward districts. This classification is made on the basis of the degree of backwardness of each district. Table 1 shows the area-wise or district-wise sanctions made by KSFC during the period under study.

\section{TABLE 1. AREA-WISE/DISTRICT-WISE ANALYSIS OF GROSS SANCTIONS}

\begin{tabular}{|l|l|r|r|r|r|}
\hline $\begin{array}{r}\text { SI. } \\
\text { No. }\end{array}$ & Name of the District & \multicolumn{2}{|c|}{$\begin{array}{c}\text { Sanctions from the } \\
\text { year } 1990-91 \text { to } \\
1997-98\end{array}$} & \multicolumn{2}{|c|}{$\begin{array}{c}\text { \%age share to } \\
\text { the state total in } \\
\text { terms of: }\end{array}$} \\
\hline I. & Backward Districts & No. & Amount & No. & Amount \\
\hline 1. & Bidar & 1,841 & $8,088.76$ & 1.95 & 2.31 \\
2. & Mysore & 6,999 & $21,546.36$ & 7.40 & 6.15 \\
3. & Dharwad & 6,972 & $21,695.35$ & 7.37 & 6.19 \\
4. & Raichur & 2,769 & $11,370.66$ & 2.93 & 3.25 \\
5. & Belgaum & 6,286 & $15,189.17$ & 6.64 & 4.34 \\
6. & Bijapur & 4,929 & $10,434.62$ & 5.21 & 2.98 \\
7. & Dakshina Kannada & 5,911 & $26,789.63$ & 6.25 & 7.65 \\
8. & Tumkur & 5,775 & $15,076.44$ & 6.10 & 4.30 \\
9. & Gulbarga & 4,918 & $8,706.52$ & 5.20 & 2.48 \\
10. & Hassan & 2,790 & $6,819.22$ & 2.95 & 1.95 \\
11. & Uttara Kannada & 1,339 & $4,058.99$ & 1.41 & 1.16 \\
\hline & Total I & 50,529 & $1,49,775.72$ & 53.41 & 42.76 \\
\hline II & Other Districts & & & & \\
\hline 12. & Bangalore & 23,248 & $1,32,940.30$ & 24.57 & 37.95 \\
13. & Shimoga & 3,545 & $8,039.67$ & 3.75 & 2.29 \\
14. & Kolar & 4,257 & $17,569.60$ & 4.50 & 5.02 \\
15. & Chitradurga & 5,239 & $14,310.75$ & 5.54 & 4.09 \\
16. & Mandya & 2,493 & $7,360.11$ & 2.63 & 2.10 \\
17. & Chickamagalur & 1,745 & $3,701.24$ & 1.84 & 1.60 \\
18. & Bellary & 2,472 & $13,133.61$ & 2.61 & 3.75 \\
19. & Kodagu & 1,085 & $3,447.73$ & 1.15 & 0.98 \\
\hline & Total II & 44,084 & $2,00,503.01$ & 46.59 & 57.24 \\
\hline & State Total (I \& II) & 94,613 & $3,50,278.73$ & 100.00 & 100.00 \\
\hline
\end{tabular}

Source: Operational Statistics of KSFC for the respective yeors.

Note: 1. The above figures exclude bridge loan, leasing finance, hire purchase assistance and merchant banking assistance.

2. The re-organisation of the state of Karnalaka by creating 7 more new districts took place in November 1997, hence not shown separately.

3. Bangalore district includes both Bangalore urban and Bangalore rural. 
Out of the 19 districts shown in Table 1, 11 districts are identified as backward districts and 8 districts are identified as non-backward districts. Among the 11 backward districts, North Karnataka part consists of 7 districts (such as Bidar, Gulbarga, Raichur, Bijapur, Belgaum, Dharwad and Uttara Kannada) and the remaining 4 districts are in South Karnataka which included Malanad and Coastal areas of the State. The 8 non-backward districts consist of only one district in North Karnataka (i.e., Bellary) and rest in South Karnataka which included Malanad region also. Thus, it is evident that except Bellary all the other districts in North Karnataka are industrially backward, thus requiring special attention.

The analysis of the Table 1 brings out the following.

1. During the 8 years under study, out of the total gross sanctions of Rs. 3,50,278.72 lakhs to 94,613 entrepreneurs, Rs. 1,49,775.72 lakhs (constituting $42.76 \%$ ) to 50.529 entrepreneurs (constituting $53.41 \%$ ) to total went to backward districts. The backward districts though got more share in terms of number, they received only $42.76 \%$ of the total sanctions made by KSFC. This shows comparatively small sized loans to large number of entrepreneurs in the backward districts.

2. Among the backward districts, Dakshina Kannada ranked first with the share of $7.65 \%$ in total assistance followed by Dhanwad (6.19\%), Mysore (6.15\%), Belgaum (4.34\%), Tumkur (4.30\%), Raichur (3.25\%), Bijapur (2.98\%), Gulbarga (2.48\%), Bidar (2.31\%), Hassan (1.95\%) and Uttara Kannada (1.16\%). It is important to note that even among the backward districts, $46.89 \%$ of the total assistance (Rs. 70,231.65 lakhs (out of Rs. 1,49,775.72 lakhs) went to 4 districts in South Karnataka (such as Dakshina Kannada, Mysore, Tumkur and Hassan), $34.30 \%$ of the assistance (Rs. 51,378.13 lakhs out of Rs. 1,49,775.72 lakhs) went to 4 districts in old Mumbai Government area/ a part of North Karnataka (such as Belgaum, Bijapur, Dharwad and Uttara Kannada) and $18.81 \%$ of the total assistance (Rs. 28,165.94 lakhs out of Rs. 1,49,775.72 lakhs) went to 3 districts of Hyderabad-Karnataka region (such as Bidar, Gulbarga and Raichur). Considering the population of these districts (which is provided in Table 2), it can be inferred that even among backward districts, the districts in North Karnataka region (more particularly Hyderabad-Karnataka region) appear to be neglected in obtaining sanctions. 
3. Among the non-backward districts, Bangalore district alone has received $37.95 \%$ of the total assistance to $24.57 \%$ of total entrepreneurs in the State and $66.30 \%$ of the assistance given to non-backward districts covering $52.73 \%$ of total number of entrepreneurs in non-backward districts.

An indepth analysis of the above figures can be made by comparing the density of population of each district with the share in the total sanctions during the period under study. Table 2 shows the density of population of each district (in terms of number and \% age), \% age share in the total sanctions of KSFC and the deficiency in due share of each district or benefit enjoyed in excess of the due share and rank secured.

TABLE 2. DENSITY OF POPULATION, SHARE IN SANCTIONS, DEFICIENCY, BENEFIT AND RANKING

\begin{tabular}{|c|c|c|c|c|c|c|c|}
\hline \multirow{2}{*}{$\begin{array}{l}\text { SI. } \\
\text { No. }\end{array}$} & \multirow{2}{*}{ Name of the District } & & \multirow{2}{*}{$\begin{array}{c}\text { \%age } \\
\text { share in } \\
\text { sanctions }\end{array}$} & \multirow{2}{*}{$\begin{array}{c}\text { Benefit } \\
1+\text { or } \\
\text { deficiency } \\
(-) \text { In due } \\
\text { Share. }\end{array}$} & \multicolumn{2}{|c|}{ Ranking } \\
\hline & & Number & $\%$ & & & $(-)$ & $(+)$ \\
\hline & 1 & 2 & 3 & 4 & $5=4-3$ & & \\
\hline 1 & Backward Districts & & & & & & \\
\hline 1. & Bidar & 643 & 2.80 & 2.31 & -0.49 & $X|| \mid$ & - \\
\hline 2. & Mysore & 1,621 & 7.06 & 6.15 & -0.91 & $x$ & - \\
\hline 3. & Dharwad & 1,802 & 7.85 & 6.19 & -1.91 & VI & - \\
\hline 4. & Raichur & 1,167 & 5.08 & 3.25 & -1.83 & V & - \\
\hline 5. & Belgaum & 1,834 & 7.99 & 4.34 & -3.65 & 1 & - \\
\hline 6. & Bijapur & 1,491 & 6.50 & 2.98 & $-3-52$ & $\|$ & - \\
\hline 7. & Dakshina Kannada & 1,306 & 5.69 & 7.65 & +1.96 & - & $\|$ \\
\hline 8. & Tumkur & 1,177 & 5.13 & 4.30 & -0.83 & $X I$ & \\
\hline 9. & Gulbargo & 1,316 & 5.73 & 2.48 & -3.25 & III & - \\
\hline 10. & Hassan & 785 & 3.42 & 1.95 & -1.47 & VIII & - \\
\hline 11. & Uttara Kannada & 621 & 2.17 & 1.16 & -1.55 & VII & - \\
\hline & Sub Total & & $\begin{array}{r}59.9 \\
\quad 6\end{array}$ & 42.76 & $\begin{array}{r}-19.16 \\
+1.96\end{array}$ & & \\
\hline
\end{tabular}


TABLE 2 (Contd.)

\begin{tabular}{|c|c|c|c|c|c|c|c|}
\hline \multirow{2}{*}{$\begin{array}{l}\text { SI. } \\
\text { No. }\end{array}$} & \multirow{2}{*}{ Name of the District } & \multicolumn{2}{|c|}{$\begin{array}{l}\text { Density of } \\
\text { Population }\end{array}$} & \multirow{2}{*}{$\begin{array}{c}\% \text { age } \\
\text { share in } \\
\text { sanctions }\end{array}$} & \multirow{2}{*}{$\begin{array}{c}\text { Benefit } \\
(+) \text { or } \\
\text { deficiency } \\
(-) \text { In due } \\
\text { Share. }\end{array}$} & \multicolumn{2}{|c|}{ Ranking } \\
\hline & & Number & $\%$ & & & $(-)$ & $(t)$ \\
\hline & 1 & 2 & 3 & 4 & $5=4-3$ & & \\
\hline$\|$ & Non-Backward Districts & & & & & & \\
\hline 12. & Bangalore & 3,403 & $\begin{array}{r}14.8 \\
3\end{array}$ & 37.95 & +23.12 & - & 1 \\
\hline 13. & Shimoga & 974 & 4.25 & 2.29 & -1.96 & IV & \\
\hline 14. & Kolar & 1,128 & 4.91 & 5.02 & +0.11 & - & III \\
\hline 15. & Chitradurgo & 1,122 & 4.89 & 4.09 & -0.80 & $x \|$ & \\
\hline 16. & Mandya & 838 & 3.65 & 2.10 & -1.55 & VII & \\
\hline 17. & Chickamagalur & 515 & 2.24 & 1.06 & -1.18 & IX & \\
\hline 18. & Bellary & 962 & 4.19 & 3.75 & -0.44 & XIV & \\
\hline 19. & Kodagu & 247 & 1.08 & 0.98 & -0.10 & $X V$ & \\
\hline & Sub Total & & $\begin{array}{r}40.0 \\
4 \\
\end{array}$ & 57.24 & $\begin{array}{r}+23.23 \\
-6.03 \\
\end{array}$ & - & - \\
\hline & Grand Total & & 100 & 100.00 & $\begin{array}{r}+25.19 \\
-25.19\end{array}$ & $\cdot$ & \\
\hline
\end{tabular}

Source: For Density of Population, Karnataka at a glance, 1992-93, Directorate of Economics and Statistics, Bangalore

It is evident from Table 2 that except Bangalore, Dakshina Kannada and Kolar districts, all other districts in the State failed to receive their due share in sanctions (facing a deficiency of $25.19 \%$ in total). Among them backward districts are the major losers with $-19.16 \%$ deficiency in total sanctions, while the deficiency rate is only $-6.03 \%$ in case of non-backward districts. Even among backward districts, the districts in north Karnataka such as Belgaum, Bijapur, Gulbarga, Raichur, Dharwad and Uttara Kannada faced a deficiency of $-3.65 \%,-3.52 \%,-3.25 \%$, $-1.83 \%,-1.66 \%$ and $-1.55 \%$ respectively and ranked first, second, third, fifth, sixth and seventh respectively among the deficiency facing districts in the State. The total deficiency of the above districts including Bidar district is $15.95 \%$, which constitutes $83.25 \%$ of the total deficiency faced by backward districts. 
The deficiency faced by all the districts in North Karnataka is $16.39 \%$ (i.e., $15.95 \%$ $+0.44 \%$ of Bellary district) which constitutes $65.05 \%$ of the deficiency faced by all the districts of the State. These figures show the continued negligence of North Karnataka even after 51 years of independence (from 1947 to 1998 is taken, since 1998 is the latest year under study).

Among the non-backward district, Bangalore district is the major recipient of the KSFC's assistance which received $23.12 \%$ more share than its legitimate share.

To conclude, this situation of injecting more and more financial assistance to a few. highly developed areas is bound to create regional imbalances. As a result, backward districts (majority in North Karnataka) which require heavy attention are being neglected. Heavy concentration of sanctions in a particular area or a part of it or a district will aggravate the position of regional imbalances instead of reducing them. A major observation that can be made here is that the KSFC appears to have given little thought to the allocation of funds among the districts. This is evident from the fact that the non-backward districts are facing minimum deficiency and getting larger share of assistance in general, and position enjoyed by Bangalore district in particular, leaving the backward districts remain backward. This is a very serious issue requiring deep thought not only for the industrialisation of North Karnataka, but also in eliminating regional imbalances.

\section{Based on these findings, the paper offers the following suggestions:}

1. The Karnataka State Government should create an 'Apex Body' subordinate to KSFC to look into the development of entrepreneurship in North Karnataka.

2. The KSFC should establish 'Technical Advise and Guidance Cell' at important places say Hubli, Belgaum and Gulbarga in North Karnataka.

3. The units coming up in these areas may be exempted from application processing fees, commitment charges, interest rate and promoter's minimum contribution.

4. Special developmental campaigns should be conducted to educate the prospective entrepreneurs. Further, more and more entrepreneurship development and awareness programmes shall be conducted for technical and non-technical students.

5. Lack of infrastructural facilities is one of the obstacles for entrepreneurship development. Therefore, the developmental agencies should develop industrial estates/areas, roads, drainage, bank, post office etc., in industrial estates as well as outside the estates. 
6. The KSFC, while fixing the target in sanctions for each district, should consider the economic situation and degree of backwardness of each district. in industrialisation. Special attention should be given to taluks and districts, which are industrially backward.

7. More systematised marketing arrangements shall be made for the entrepreneurs.

To conclude, the suggestions made above are, if implemented in good faith, would reduce the backwardness of North Karnataka and give justice to it and reduce the feeling of having a separate 'North Karnataka State'.

\section{References}

1. Bhanushali S.G., Entrepreneurship Development, New Delhi: Himalaya Publishing House, 1987.

2. Desai Aravindrai N, Environment and Entrepreneur, New Delhi: Ashish Publishing House, 1989.

3. Desai Vasanth, Dynamics of Entrepreneurial Development, Bombay: Himalaya Publishing House, 1991.

4. Desai Vasanth, Entrepreneurial Development - Volume - 1, Bombay: Himalaya Publishing House, 1991.

5. Desai Vasanth, Entrepreneurial Development - Volume - 3, Bombay: Himalaya Publishing House, 19.91.

6. Deshpande Manohar U, Entrepreneurship of Small Scale Industry-Concept, Growth and Management, Delhi: Deep and Deep Publication, 1989.

7. Dhar P.N. and Lydoll H.F., Role of Small Entrepreneurs in Indian Economic Development, Asia Publishing House, Bombay, 1961, p. 70.

8. Drucker Peter F, Innovation and Entrepreneurship, Practice and Principles, New Delhi: Affiliated East-West Press Pvt. Ltd., 1991.

9. Haggen E.E., The Economics of Development, p. 219 cited in Vasanth Desai, Entrepreneurship Development, Vol 1, Himalaya Publishing House, Bombay, 1991. 
10. Kannan Gnana, "Training for Entrepreneurship Development" in Developing Entrepreneurship-Issues and Problems, SIET Hyderabad, 1980, p. 118 cited in N.C. Pillai and Anna V, "The Entrepreneurial Spirit Among Women" Indian Management, Vol. 29, 11-12, 1990, pp. 93-98.

11. Management Development Institute, New Delhi, Small Scale Industries - An Assessment of Institutional Assistance, Case Studies of some select States in India, 1983, pp. 137.

12. Rao A.S., Entrepreneurship and Performance of Enterprises - A Case Study of Chemical Industry, p. 240 cited in R.S. Jalal (Ed) Industrial Entrepreneurship and Small Scale Industries. Anmol Publications, New Delhi, 1991.

13. Sharma, Krishnalal and Singh, Harnek, Entrepreneurial Growth and Development Prógrammes in Northern India. A Sociological Analysis, New Delhi, Abhinav Publications, 1980.

\section{Reports}

1. Report on "The Role of Commercial Banks in Financing and Promoting the Small Entrepreneurs. A study of Karnataka-State by Dr. Anitha. H.S. An UGC Major Research Project Report submitted to UGC during December, 2001.

2. Report of the committee on banking sector reforms headed by M. Narasimham, April 1998.

3. Report on currency and finance, Vol. 1 (Economic review) and Vol. 2 (Statistical Statements), RBI, 1996-97, 1999-2000.

4. Report on Trend and Progress of Banking in India, RB| 1992-93, 1994-95, 1996-97, 1997-98, 1999-2000.

5. Statistical Abstract of Karnataka, Directorate of Economics and Statistics, Bangalore, 1993-94, 1997. 